\title{
ESR1 gene polymorphisms Pvull (rs2234693T>C) and Xbal (rs9340799A>G) may not be directly correlated with cardiovascular disease risk
}

N. Jiang, G. Yang and C.L. Peng

The Third Department of Cardiovascular,

The First Hospital Affiliated Heilongjiang University of TCM, Xiangfang, Harbin,

Heilongjiang, China

Corresponding author: N. Jiang

E-mail:jiangning0105@126.com

Genet. Mol. Res. 14 (4): 13932-13944 (2015)

Received May 14, 2015

Accepted August 31, 2015

Published October 29, 2015

DOI http://dx.doi.org/10.4238/2015.October.29.14

ABSTRACT. The aim of this meta-analysis was to evaluate the correlations between the estrogen receptor 1 (ESR1) gene polymorphisms Pvull (rs2234693T $>C$ ) and $X$ bal (rs9340799A $>G$ ) and the risk of cardiovascular disease (CVD). Case-control studies were screened and selected from a larger group of studies that were retrieved through a comprehensive search of scientific literature databases, which was complemented by manual searches. Data from studies selected were analyzed using the Comprehensive Metaanalysis 2.0 software. A total of 240 studies were initially retrieved and 10 studies were eventually included in the meta-analysis. These 10 case-control studies involved 7029 CVD patients (5001 myocardial infarction patients, 1223 coronary artery disease patients, 805 acute coronary syndromes patients) and 6901 healthy controls. We found no significant association between the Pvull (rs2234693T $>$ C) and Xbal (rs9340799A $>$ G) polymorphisms and CVD risk. We detected no significant associations under all genetic inheritance models tested, including the allele, dominant, homozygous, heterozygous, 
and recessive models, or for comparisons between the case group and control group (all $\mathrm{P}>0.05$ ). Our meta-analysis results strongly suggest that the ESR1 gene polymorphisms Pvull (rs2234693T>C) and Xbal (rs9340799A>G) are not associated with CVD risk.

Key words: Acute coronary syndromes; Cardiovascular disease; Coronary artery disease; Estrogen receptor 1; Meta-analysis; Myocardial infarction

\section{INTRODUCTION}

Cardiovascular disease (CVD) is the leading cause of morbidity and mortality worldwide, and refers to any disease of the cardiovascular system, principally consisting of cardiac diseases, peripheral arterial diseases, and vascular diseases of the brain and kidney (Ovbiagele et al., 2013). CVD encompasses a wide range of conditions, including myocardial infarction (MI), coronary artery disease (CAD), and acute coronary syndromes (ACS) (Wang et al., 2011). It is estimated that over $80 \%$ of deaths worldwide are caused by CVD. CVD incidence rates are higher in lowand middle-income countries, and more than 23 million people may die from CVD each year by 2030 (Taylor et al., 2013). CVD-related morbidity and mortality in China are projected to increase substantially, both in absolute numbers and as a proportion of total disease burden, over the next 20 years (Taylor et al., 2011). The pathogenesis of CVD is diverse, including both genetic and environmental factors (Wang et al., 2011). Accordingly, the risk factors for CVD are varied and include age, gender, obesity, high blood pressure, hyperlipidemia, sugar consumption, family history, diabetes mellitus, psychosocial factors, tobacco smoking, processed meat consumption, excessive alcohol consumption, lack of physical activity, and air pollution (Finks et al., 2012; Micha et al., 2012). The social burden of CVD is high, involving significant costs in management and treatment, reduced economic activity, and impaired quality of life; CVD also imposes major stress on limited health resources (Zomer et al., 2012). Consequently, early diagnosis and prevention are critical for disease management. Recent studies have shown that estrogen-related genes are associated with a significantly increased risk of CVD (Li et al., 2012).

Estrogen receptor 1 (ESR1) is an essential member of the nuclear hormone receptor super family and serves as a ligand-activated transcription factor composed of several domains important for DNA binding, hormone binding, and transcription activation (Cheng et al., 2014). ESR1 is mainly expressed in macrophages, endothelial cells, and vascular smooth muscle cells, and it plays an important role in vascular wall physiology and function (Gao et al., 2014). The ESR1 gene, spanning approximately $25 \mathrm{~kb}$, is located on chromosome 6q21 and consists of 16 exons (Drayna et al., 1987). ESR1 gene polymorphisms are linked to cancer, hip fracture, CAD, and bone mineral density (Gu et al., 2014; Lu et al., 2014). Single-nucleotide polymorphisms in the ESR1 gene have been associated with vascular diseases and conditions, such as arterial hypertension, CVD, cerebrovascular disease, and serum lipid level alterations (Markoula et al., 2012). The 2 most widely examined variants of ESR1 are located in intron 1, at 397 and 351 base pairs upstream of exon 2, and are often identified by their restriction endonuclease recognition sites, Pvull and Xbal, respectively (Bos et al., 2008). The Pvull restriction site polymorphism is associated with rs2234693 (397T>C), while the Xbal restriction site polymorphism involves rs9340799 (351A>G) (Kunnas et al., 2010). Previous studies examining the contribution of the ESR1 polymorphisms 
Pvull (rs2234693T>C) and Xbal (rs9340799A > G) revealed that they were strongly correlated with CVD susceptibility (Xu et al., 2008; Boroumand et al., 2009) or that there were links with CVD in different study populations (Xing et al., 2013).In order to address these issues, a meta-analysis was performed based on previous reports to assess the associations between the ESR1 gene Pvull (rs2234693T>C) and Xbal (rs9340799A>G) polymorphisms and the risk of CVD.

\section{MATERIAL AND METHODS}

\section{Search strategy}

A comprehensive search was conducted to identify case-control studies evaluating the correlations between the ESR1 gene Pvull (rs2234693 T>C) and Xbal (rs9340799 A>G) polymorphisms and CVD using scientific literature databases such as PubMed, Web of Science, Cochrane Library, Springerlink, Wiley, EBSCO, Ovid, Wanfang database, VIP database, and China National Knowledge Infrastructure to identify studies published prior to October 2014. The search terms used included the following: (myocardial infarction" or "myocardial infarct" or "AMI" or "myocardial necrosis" or "cardiac necrosis" or "myocardiolysis") and ("coronary disease" or "coronary heart disease" or "CHD" or "CAD") and ("estrogen receptor alpha" or "eralpha" or "estrogen receptor 1" or "ESR1"). No language restrictions were used in our search. We also performed manual searches to retrieve other potential cross-references.

\section{Inclusion and exclusion criteria}

The inclusion criteria were as follows: 1) research topic: correlations between ESR1 gene Pvull (rs2234693 T>C) and Xbal (rs9340799 A>G) and CVD; 2) study type: case-control studies; 3) study subjects: the case group included patients clinically diagnosed with CVD and the control group included healthy controls; 4) end indicators: allele and genotype frequencies in the case group and control group; 5) studies were published in Chinese or in English. The exclusion criteria were: 1) reviews or articles with only abstracts; 2) animal research; 3) duplicate publications or unpublished literature; 4) studies with insufficient data; 5) if more than one study was published by the same author using the same case series, we selected the study with the largest series.

\section{Statistical analysis}

The meta-analysis was conducted using Comprehensive Meta-analysis 2.0 software (Biostatic Inc., Englewood, NJ, USA). The odds ratio (OR) at $95 \% \mathrm{Cl}$ was used to evaluate the differences in allele and genotype frequencies between CVD patients and healthy controls. The $Z$ test was applied to evaluate the significance of the overall effect size (Chen et al., 2012). Forest plots were drawn to reflect the comparisons of $\mathrm{OR}$ and $95 \% \mathrm{Cl}$ among the study groups. Heterogeneity among studies was evaluated by Cochran's $Q$ test and the $I^{2}$ statistic (Peters et al., 2006; Jackson et al., 2012). A P value of less than 0.05 was considered statistically significant. When there was no evidence of heterogeneity $\left(I^{2}\right.$ values $\left.<50 \%\right)$, a fixed-effects model was utilized to calculate parameters. If there was substantial heterogeneity ( $I^{2}$ values $\geq 50 \%$ ), the randomeffects model was used to pool data (Zintzaras and loannidis, 2005). Univariate and multivariate meta-regression analyses were utilized to identify potential sources of heterogeneity, which were 
further confirmed by Monte Carlo Stimulation (Ferrenberg and Swendsen, 1988; Huizenga et al., 2011). Sensitivity analysis was performed to assess whether the results had significant influences on the overall outcomes by deleting single studies individually. Funnel plots, classic fail-safe $\mathrm{N}$, and Egger's linear regression test were used to detect publication bias to confirm the reliability of the original analysis results (Egger et al., 1997; Wikstrom et al., 2009).

\section{RESULTS}

\section{Baseline characteristics of included studies}

The electronic literature search and manual search identified a total of 240 relevant articles. After excluding 22 duplicates studies, 5 letters and reviews, 4 non-human studies, and 6 non-English or non-Chinese studies, a total of 203 full-text articles remained. After further assessing the remaining articles, 193 studies were excluded for the following reasons: 15 for noncase-control study, 6 for duplicate publications or unpublished articles, 141were irrelevant to CVD, 30 were irrelevant to ESR1, and 1 contained incomplete data or weakly correlated data. Finally, 10 studies were incorporated in this meta-analysis (Koch et al., 2005; Mansur Ade et al., 2005; Almeida and Hutz, 2006; Alevizaki et al., 2007; Kjaergaard et al., 2007; Morgan et al., 2007; Xu et al., 2008; Karadağ et al., 2009; Lluís-Ganella et al., 2009; Roszkowska-Gancarz et al., 2010). The 10 eligible studies were published from 2003 to 2014 and included a total of 7029CVD patients and 6901 healthy controls. The patient group consisted of $5001 \mathrm{Ml}$ patients, $1223 \mathrm{CAD}$ patients, and 805 ACS patients. Sample sizes in the studies varied between 157-4868 subjects. Of the 10 casecontrol studies, only 1 study was conducted in Asians (China), while 9 studies were performed in Caucasians, with 1 study each in Germany, the US, Greece, Denmark, Turkey, Spain, and Poland, and 2 studies from Brazil. This meta-analysis examined the ESR1 gene polymorphisms rs2234693 and rs9340799 (Figure 1). Single-nucleotide polymorphism detection methods included polymerase chain reaction with the restriction fragment length polymorphism (PCR-RFLP) and TaqMan assays. The baseline characteristics of the included studies are shown in Table 1.

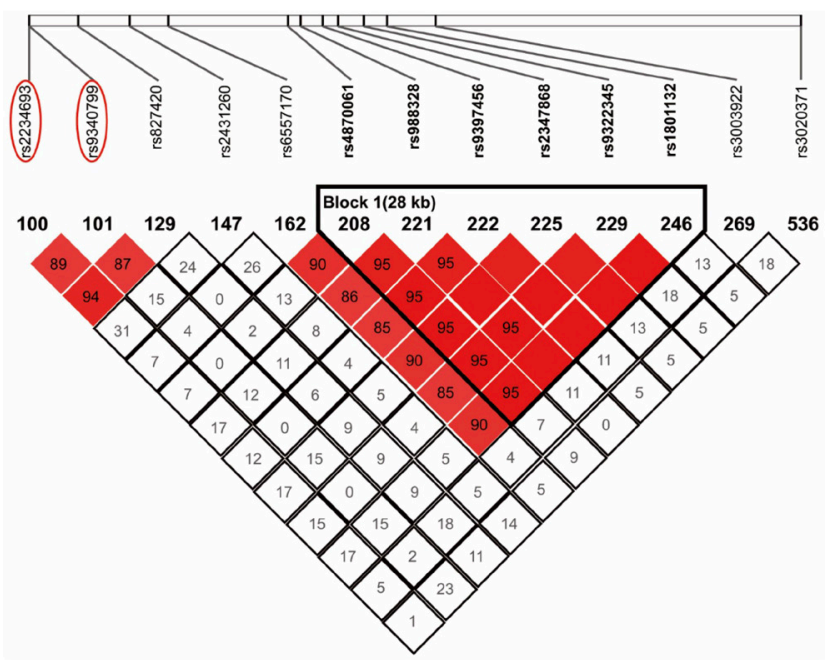

Figure 1. Schematic diagram of ESR1 gene polymorphisms Pvull (rs2234693T>C) and Xbal (rs9340799A>G). 
N. Jiang et al.

13936

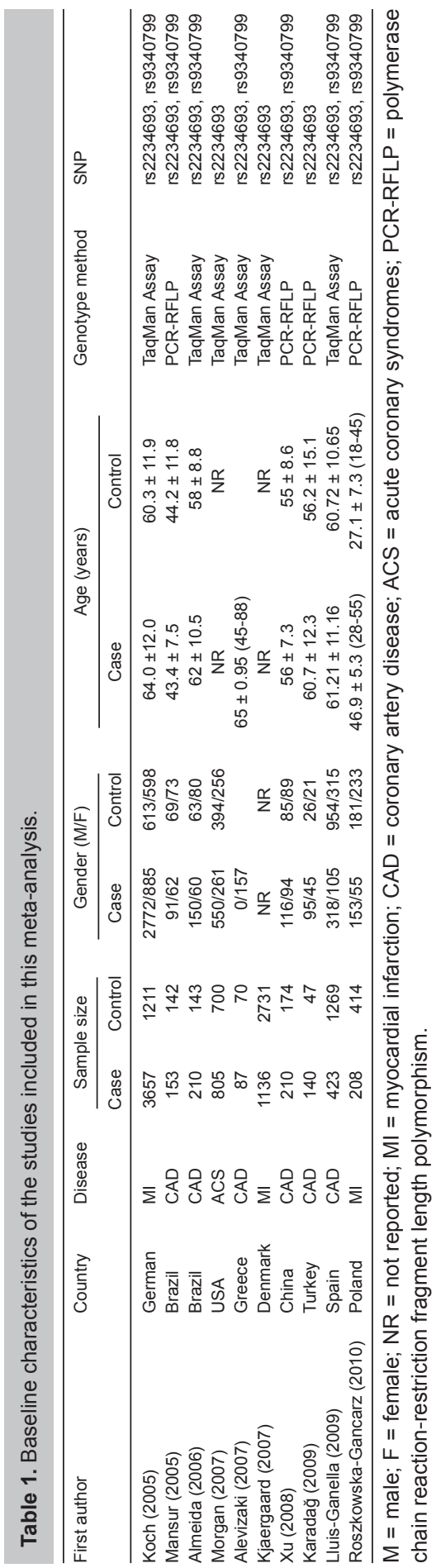




\section{Association between Pvull (rs2234693T>C) and CVD risk}

All 10 studies reported the correlations between the ESR1 gene Pvull (rs2234693T>C) and CVD risk. No heterogeneity was observed among the studies, and thus the fixed-effects model was used under the allele model and the dominant model (allele model: $I^{2}=41.059 \%, \mathrm{P}$ $=0.084$; dominant model: $\left.I^{2}=26.730 \%, \mathrm{P}=0.198\right)$. The results of the meta-analysis showed no significant association between Pvull (rs2234693T>C) and CVD risk, and no significant association was found under the allele, dominant, homozygous, heterozygous, and recessive models regarding comparisons between the case group and the control group (allele model: OR $=1.014,95 \% \mathrm{Cl}=0.963-1.069, \mathrm{P}=0.593$; dominant model: $\mathrm{OR}=1.039,95 \% \mathrm{Cl}=0.957-1.127$, $\mathrm{P}=0.361$; homozygous model: $\mathrm{OR}=1.026,95 \% \mathrm{Cl}=0.922-1.142, \mathrm{P}=0.640$; heterozygous model: $\mathrm{OR}=1.020,95 \% \mathrm{Cl}=0.926-1.123, \mathrm{P}=0.689 ;$ recessive model: $\mathrm{OR}=0.995,95 \% \mathrm{Cl}$ $=0.909-1.090, P=0.920$ ) (Figure $2 A-B$ and Table 2). Subgroup analysis based on disease type revealed no significant association between Pvull (rs2234693T $>C$ ) and the risk of MI, CAD, and ACS, and no significant associations under allele and genotype frequencies in the case group and control group (allele model: $\mathrm{MI}$ : $\mathrm{OR}=0.979,95 \% \mathrm{Cl}=0.918-1.044, \mathrm{P}=0.518$; CAD: $O R=1.072,95 \% C l=0.959-1.199, P=0.219 ; A C S: O R=1.105,95 \% C l=0.955-1.280, P$ $=0.18$; dominant model: $\mathrm{MI}: \mathrm{OR}=0.978,95 \% \mathrm{Cl}=0.885-1.081, \mathrm{P}=0.668 ; \mathrm{CAD}: \mathrm{OR}=1.129$, $95 \% \mathrm{Cl}=0.955-1.334, \mathrm{P}=0.155 ; \mathrm{ACS}: \mathrm{OR}=1.269,95 \% \mathrm{Cl}=0.980-1.643, \mathrm{P}=0.071)($ Table 2). A second subgroup analysis based on the genotyping method also revealed no significant association between Pvull (rs2234693T>C) and the risk of CVD using PCR-RFLP and TaqMan assays, and no significant association was found under the allele and genotype frequencies in the case group and control group (allele model: PCR-RFLP: OR $=0.967,95 \% \mathrm{Cl}=0.829-1.127$, $\mathrm{P}=0.664$; TaqMan assay: $\mathrm{OR}=1.021,95 \% \mathrm{Cl}=0.966-1.079, \mathrm{P}=0.468$; dominant model: PCR-RFLP: $\mathrm{OR}=0.951,95 \% \mathrm{Cl}=0.757-1.193, \mathrm{P}=0.662 ;$ TaqMan assay: $\mathrm{OR}=1.052,95 \% \mathrm{Cl}$ $=0.964-1.148, P=0.252$ ) (Table 2). The results of meta-regression analysis suggested that publication year, sample size, disease type, and genotyping methods were not the main source for heterogeneity or key factors influencing the overall effect values (all P>0.05) (Figure 3A-D and Table 3).
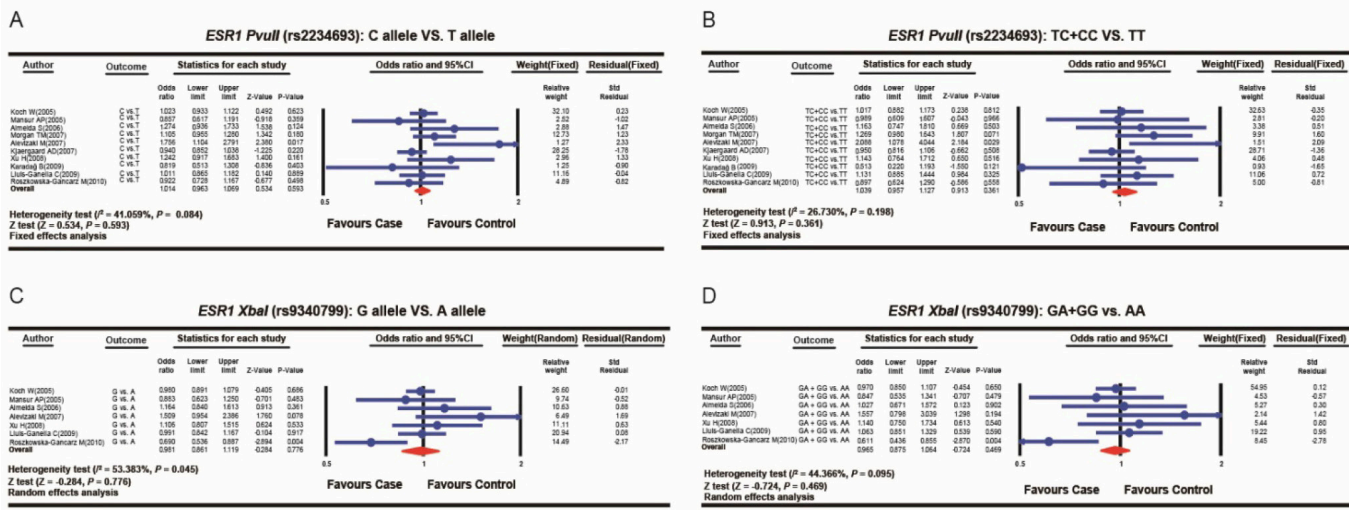

Figure 2. Forest plots for allele and genotype frequencies of ESR1 gene polymorphisms Pvull (rs2234693T>C) and $X$ bal (rs9340799A>G) in the case group and the control group. 
Table 2. Comparisons of genotype and allele frequencies between the case and the control groups.

\begin{tabular}{|c|c|c|c|c|c|c|c|c|}
\hline \multirow{2}{*}{$\begin{array}{l}\text { SNP } \\
\text { Gene model }\end{array}$} & & & \multicolumn{3}{|c|}{$\mathrm{rs} 2234693 \mathrm{~T}>\mathrm{C}$} & \multicolumn{3}{|c|}{ rs9340799 A>G } \\
\hline & & & OR & $95 \% \mathrm{Cl}$ & $\mathrm{P}$ & OR & $95 \% \mathrm{Cl}$ & $P$ \\
\hline \multirow[t]{6}{*}{$\mathrm{M}$ allele $v s \mathrm{~W}$ allele (Allele model) } & Overall & & 1.014 & $0.963-1.069$ & 0.593 & 0.981 & $0.861-1.119$ & 0.776 \\
\hline & Genotyping methods & TaqMan Assay & 1.021 & 0.966-1.079 & 0.468 & 1.006 & $0.929-1.088$ & 0.888 \\
\hline & & PCR-RFLP & 0.967 & $0.829-1.127$ & 0.664 & 0.841 & $0.709-0.999$ & 0.048 \\
\hline & Disease & MI & 0.979 & $0.918-1.044$ & 0.518 & 0.938 & $0.857-1.026$ & 0.159 \\
\hline & & CAD & 1.072 & $0.959-1.199$ & 0.219 & 1.044 & $0.927-1.177$ & 0.476 \\
\hline & & ACS & 1.105 & $0.955-1.280$ & 0.18 & - & - & - \\
\hline \multirow[t]{6}{*}{ WM + MM vs WW (Dominant model) } & Overall & & 1.039 & $0.957-1.127$ & 0.361 & 0.965 & $0.875-1.064$ & 0.469 \\
\hline & Genotyping methods & TaqMan Assay & 1.052 & $0.964-1.148$ & 0.252 & 1.007 & $0.904-1.122$ & 0.896 \\
\hline & & PCR-RFLP & 0.951 & $0.757-1.193$ & 0.662 & 0.796 & $0.634-1.000$ & 0.05 \\
\hline & Disease & MI & 0.978 & $0.885-1.081$ & 0.668 & 0.912 & $0.807-1.031$ & 0.142 \\
\hline & & CAD & 1.129 & $0.955-1.334$ & 0.155 & 1.063 & $0.904-1.249$ & 0.46 \\
\hline & & ACS & 1.269 & $0.980-1.643$ & 0.071 & - & - & - \\
\hline \multirow[t]{6}{*}{ MM vs WW (Homozygous model) } & Overall & & 1.026 & $0.922-1.142$ & 0.64 & 0.969 & $0.837-1.123$ & 0.68 \\
\hline & Genotyping methods & TaqMan Assay & 1.039 & $0.928-1.164$ & 0.505 & 1.008 & $0.846-1.200$ & 0.931 \\
\hline & & PCR-RFLP & 0.922 & $0.666-1.276$ & 0.624 & 0.769 & $0.539-1.096$ & 0.147 \\
\hline & Disease & MI & 0.957 & $0.840-1.090$ & 0.506 & 0.898 & $0.740-1.090$ & 0.275 \\
\hline & & CAD & 1.141 & $0.896-1.452$ & 0.285 & 1.076 & $0.825-1.405$ & 0.588 \\
\hline & & ACS & 1.26 & $0.934-1.701$ & 0.13 & - & - & - \\
\hline \multirow[t]{6}{*}{ WM vs MM (Heterozygous model) } & Overall & & 1.02 & $0.926-1.123$ & 0.689 & 1.019 & $0.871-1.191$ & 0.818 \\
\hline & Genotyping methods & TaqMan Assay & 1.022 & $0.924-1.132$ & 0.668 & 0.998 & $0.840-1.186$ & 0.981 \\
\hline & & PCR-RFLP & 0.998 & $0.738-1.348$ & 0.987 & 1.122 & $0.772-1.631$ & 0.547 \\
\hline & Disease & MI & 1.032 & $0.916-1.163$ & 0.602 & 1.024 & $0.845-1.240$ & 0.81 \\
\hline & & CAD & 0.986 & $0.789-1.231$ & 0.899 & 1.008 & $0.769-1.322$ & 0.953 \\
\hline & & ACS & 1.01 & $0.795-1.284$ & 0.932 & - & - & - \\
\hline \multirow[t]{6}{*}{ MM vs WW + WM (Recessive model) } & Overall & & 0.995 & $0.909-1.090$ & 0.92 & 0.969 & $0.837-1.123$ & 0.68 \\
\hline & Genotyping methods & TaqMan Assay & 0.998 & $0.907-1.099$ & 0.975 & 1.003 & $0.852-1.181$ & 0.972 \\
\hline & & PCR-RFLP & 0.968 & $0.728-1.287$ & 0.823 & 0.838 & $0.598-1.176$ & 0.307 \\
\hline & Disease & MI & 0.965 & $0.862-1.079$ & 0.529 & 0.938 & $0.782-1.124$ & 0.486 \\
\hline & & CAD & 1.055 & $0.853-1.305$ & 0.621 & 1.034 & $0.804-1.331$ & 0.794 \\
\hline & & ACS & 1.059 & $0.844-1.329$ & 0.621 & - & - & - \\
\hline
\end{tabular}

SNP = single-nucleotide polymorphisms; OR = odds ratio; $95 \% \mathrm{Cl}=95 \%$ confidential intervals; $\mathrm{Ml}=\mathrm{myocardial}$ infarction; $\mathrm{CAD}=$ Coronary artery disease; $\mathrm{ACS}$ = acute coronary syndromes; PCR-RFLP = polymerase chain reactionrestriction fragment length polymorphism.

\section{Association between Xbal (rs9340799A>G) and CVD risk}

Seven studies evaluated the correlations between ESR1 gene Xbal (rs9340799A>G) and CVD risk. Because of evidence of heterogeneity in the heterogeneity tests, the random-effects model was used under the allele model $\left(I^{2}=53.383 \%, P=0.045\right)$, while the fixed-effects model was utilized for the absence of heterogeneity under the dominant model $\left(I^{2}=44.366 \%, P=0.095\right)$. Pooled data from this meta-analysis revealed no significant association between Xbal (rs9340799A>G) and CVD risk, and no significant association was found under the allele, dominant, homozygous, heterozygous, and recessive models in comparisons of the case group and the control group (allele model: $\mathrm{OR}=0.981,95 \% \mathrm{Cl}=0.861-1.119, \mathrm{P}=0.776$; dominant model: $\mathrm{OR}=0.965,95 \% \mathrm{Cl}$ $=0.875-1.064, \mathrm{P}=0.469$; homozygous model: $\mathrm{OR}=0.969,95 \% \mathrm{Cl}=0.837-1.123, \mathrm{P}=0.680$; heterozygous model: $\mathrm{OR}=1.019,95 \% \mathrm{Cl}=0.871-1.191, \mathrm{P}=0.818$; recessive model: $\mathrm{OR}=0.969$, $95 \% \mathrm{Cl}=0.837-1.123, \mathrm{P}=0.680$ ) (Figure 2C-D and Table 2). Subgroup analysis based on disease type demonstrated that there was no significant association between $X b a l$ ( $r s 9340799 A>G)$ and the risk of $\mathrm{MI}$ and CAD, and no significant association was observed for allele and genotype frequencies in the case group and control group (allele model: $\mathrm{Ml}$ : $\mathrm{OR}=0.938,95 \% \mathrm{Cl}=0.857$ 1.026, $\mathrm{P}=0.159$; $\mathrm{CAD}: \mathrm{OR}=1.044,95 \% \mathrm{Cl}=0.927-1.177, \mathrm{P}=0.476$; dominant model: $\mathrm{Ml}: \mathrm{OR}=$ 
0.912, 95\%Cl =0.807-1.031, $\mathrm{P}=0.142 ; \mathrm{CAD}: \mathrm{OR}=1.063,95 \% \mathrm{Cl}=0.904-1.249, \mathrm{P}=0.460)($ Table 2). A second subgroup analysis based on genotyping method revealed that $X b a l$ ( $r s 9340799 A>G$ ) was associated with CVD risk for the PCR-RFLP method and there was a significant association under the allele model in the case group and control group $(\mathrm{OR}=0.841,95 \% \mathrm{Cl}=0.709-0.999, \mathrm{P}$ $=0.048$ ); however, no significant association was observed for the TaqMan assay (Table 2). The results of meta-regression analysis suggested that publication year, sample size, disease type, and genotyping method were not the main sources of heterogeneity and the key factors influencing the overall effect values (all P > 0.05) (Figure 3E-H and Table 4).

A

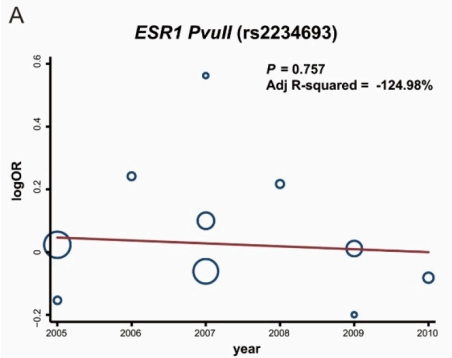

C

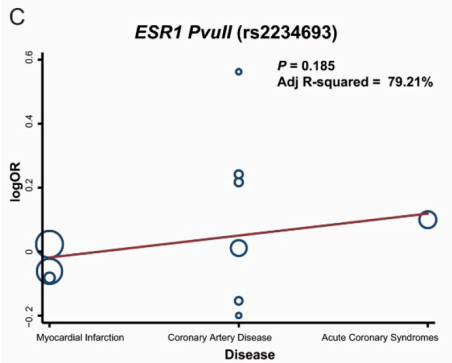

$\mathrm{E}$
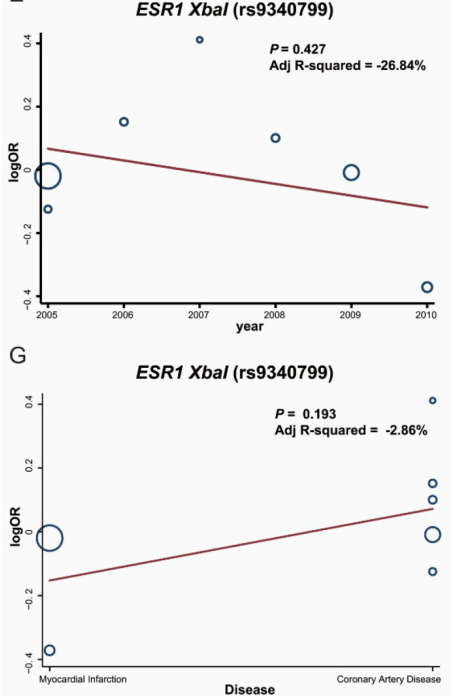

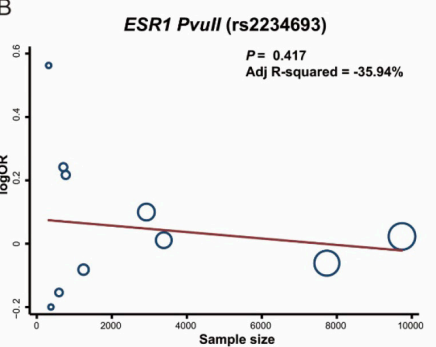

D

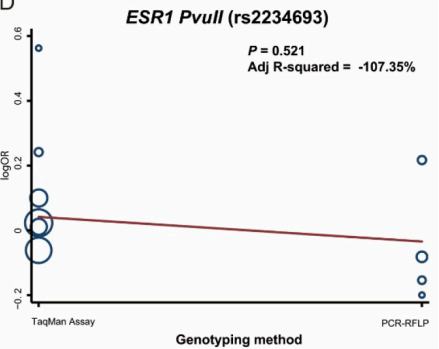

$\mathrm{F}$

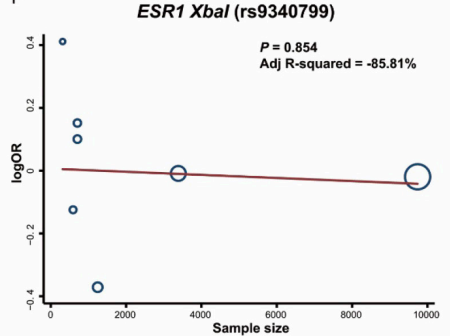

$\mathrm{H}$

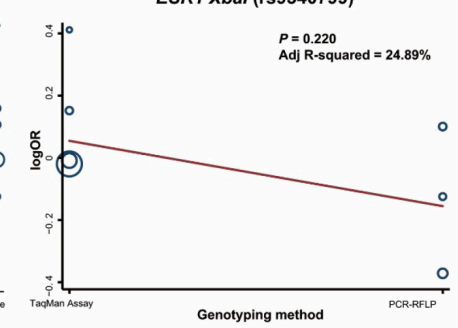

Figure 3. Meta-regression analysis for allele and genotype frequencies of ESR1 gene polymorphisms Pvull ( $r$ 2234693T $>C$ ) and $X$ bal ( $r$ 9340799A $>$ G) in the case group and the control group. 


\begin{tabular}{|c|c|c|c|c|c|c|}
\hline \multirow[t]{2}{*}{ Heterogeneity factors } & \multirow[t]{2}{*}{ Coefficient } & \multirow[t]{2}{*}{ SE } & \multirow[t]{2}{*}{$\mathrm{t}$} & \multirow[t]{2}{*}{ P (Adjusted) } & \multicolumn{2}{|c|}{$95 \% \mathrm{Cl}$} \\
\hline & & & & & LL & UL \\
\hline Year & -0.037 & 0.037 & -1.01 & 0.588 & -0.131 & 0.057 \\
\hline Sample size & 0 & 0 & -1.29 & 0.417 & -0.0001 & 0 \\
\hline Disease & -0.039 & 0.11 & -0.36 & 0.969 & -0.322 & 0.243 \\
\hline Genotyping methods & -0.228 & 0.179 & -1.27 & 0.421 & -0.688 & 0.232 \\
\hline
\end{tabular}

SE = standard error; LL = lower limit; UL = upper limit.

Table 4. Meta-regression analyses of potential source of heterogeneity ESR1 (rs9340799A>G).
\begin{tabular}{lcccccc}
\hline Heterogeneity factors & Coefficient & SE & $t$ & P (Adjusted) & U5\%Cl \\
\cline { 3 - 6 } & & & & 0.884 & -0.256 & 0.189 \\
\hline Year & -0.034 & 0.052 & -0.65 & 0.987 & -0.0002 & 0.0002 \\
Sample size & 0 & 0 & -0.26 & 0.899 & -1.073 & 1.429 \\
Disease & 0.178 & 0.291 & 0.61 & 0.771 & -1.267 & 0.813 \\
Genotyping methods & -0.227 & 0.242 & -0.94 & & & UL \\
\hline
\end{tabular}

SE = standard error; LL = lower limit; UL = upper limit.

\section{Sensitivity analysis and publication bias}

Sensitivity analysis showed that none of the included studies significantly affected the pooled OR evaluating the correlation between ESR1 gene Pvull (rs2234693T>C) and Xbal (rs9340799A >G) and CVD risk (Figure 4). The funnel plot was symmetrical, indicating no significant publication bias. Classic fail-safe $\mathrm{N}$ and Egger's linear regression test further confirmed that there was no publication bias (both $\mathrm{P}>0.05$ ) (Figure 5).
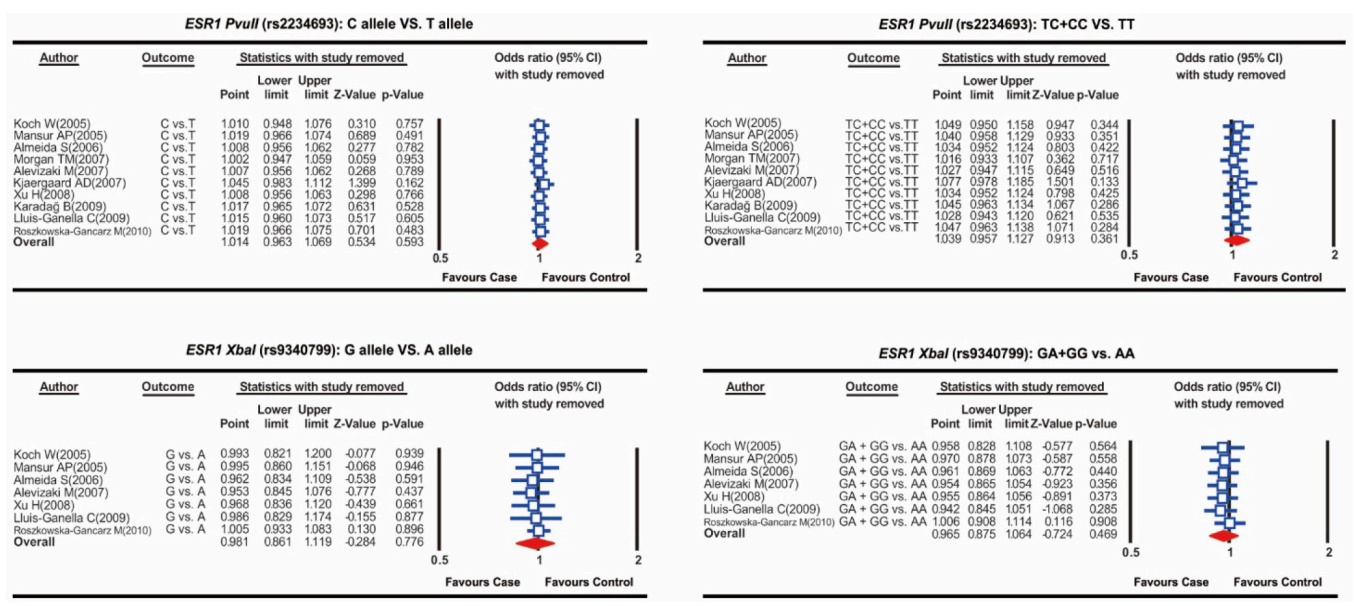

Figure 4. Sensitivity analysis for allele and genotype frequencies of ESR1 gene polymorphisms Pvull (rs2234693T>C) and $\mathrm{Xbal}$ (rs9340799A>G) in the case group and the control group.

Genetics and Molecular Research 14 (2): 13932-13944 (2015) 


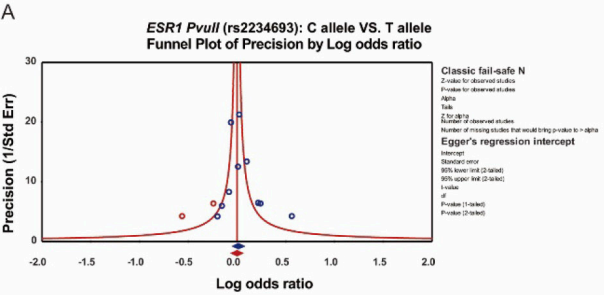

C

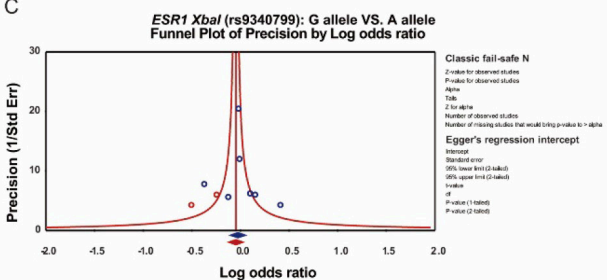

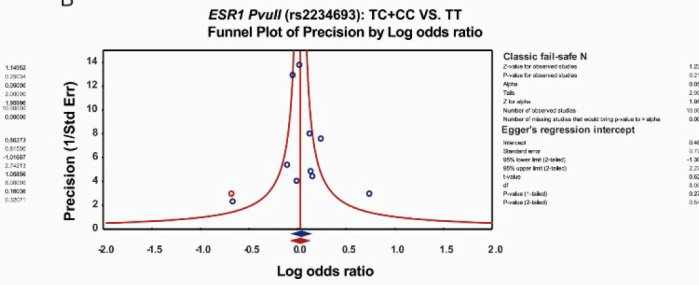

D

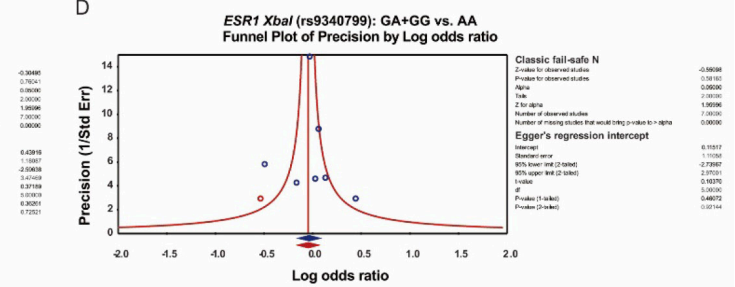

Figure 5. Funnel plot of publication biases on allele and genotype frequencies of ESR1 gene polymorphisms Pvull ( $r$ 2234693T>C) and Xbal (rs9340799A > G) in the case group and the control group.

\section{DISCUSSION}

In order to investigate the associations between the ESR1 gene Pvull (rs2234693T>C) and $\mathrm{Xbal}$ (rs9340799A>G) polymorphisms and the risk of CVD, we conducted a meta-analysis. In this study, we found no significant correlations between the ESR1 gene Pvull (rs2234693T>C) and Xbal (rs9340799A>G) polymorphisms and the risk of CVD. ESR1 is a ligand-activated transcription factor that plays an important role in vascular physiology and is involved in regulating multiple cellular pathways. ESR1 protein is expressed in human vascular endothelial and smooth muscle cells, and transgenic mice experiments have shown that ESR1 accelerates reendothelialization, stimulates endothelial nitric oxide production, and inhibits the vascular injury response (Roforth et al., 2014). Estrogen receptors can affect the estrogen action at the tissue level, and thus play an essential role in the development of severe CAD in postmenopausal women (Alevizaki et al., 2007). The false-negative results, or a failure to identify statistically significant correlations among the genotypes, in this meta-analysis may have resulted for the following reasons: first, the genotype and haplotype frequencies in the case and control groups were well-correlated with the findings of independent studies that included Caucasians populations; second, repetition of genotyping methods with TaqMan assays yielded reliable data with the use of PCR-RFLP, supporting our results (Ding et al., 2014). Other factors lead to false-negative results. Population stratification may be a major reason for inconsistent observations in Caucasians. Heterogeneity in our selection criteria used for study inclusion may also explain the disparate findings among studies (Koch et al., 2005). The inability to identify a correlation between the ESR1 gene Pvull (rs2234693T>C) and Xbal (rs9340799A $>$ G) polymorphisms and the risk of CVD suggested that these polymorphisms have a modest influence on CVD disease pathogenesis. The disease phenotype may be more strongly impacted by other factors such as genetic factors and environmental and lifestyle influences. In contrast, future studies focused on other ethnic groups may reveal the influence of the ESR1 gene Pvull (rs2234693T>C) and Xbal (rs9340799A >G) polymorphisms, which may be due to genetic interactions with other divergent gene loci. 
Subgroup analysis was carried out to further explore the influence of other factors such as disease type and genotyping method, on the correlation between ESR1 gene Pvull ( $r$ 2234693T>C) and $X$ bal ( $r$ 9340799A $>$ G) and the risk of CVD. Subgroup analysis based on disease type revealed no significant association between Pvull (rs2234693T>C) and the risk of MI, CAD, and ACS, and no significant association was found between Xbal (rs9340799A>G) and the risk of $\mathrm{MI}$ and $\mathrm{CAD}$. A second subgroup analysis based on genotyping method revealed no significant association between Pvull (rs2234693T>C) and the risk of CVD when detected by PCRRFLP and TaqMan assay. Xbal (rs9340799A $>$ G) was associated with CVD risk with the application of PCR-RFLP, while no significant association was observed with TaqMan assay detection. The subgroup analyses showed that the differences in disease type and genotyping method had no marked effects on the overall outcomes.

There were limitations to the present meta-analysis. The different genotyping methods used may have contributed to heterogeneity in the overall results. Another concern is that only one study involved an Asian population, while the remaining studies were performed in Caucasians, which may have had a negative influence on the validity of overall results. Additionally, the comparatively small sample size used in our meta-analysis may have also reduced reliability of the results. Finally, manual searching of relevant reviews may have resulted in the omission of studies and thus impacted the overall results.

In summary, these meta-analysis results strongly indicate that there is no significant correlation between the ESR1 gene Pvull (rs2234693T>C) and Xbal (rs9340799A $>$ G) polymorphisms and CVD risk.

\section{Conflicts of interest}

The authors declare no conflict of interest.

\section{ACKNOWLEDGMENTS}

We would like to thank our instructors for valuable advice.

\section{REFERENCES}

Alevizaki M, Saltiki K, Cimponeriu A, Kanakakis I, et al. (2007). Severity of cardiovascular disease in postmenopausal women: associations with common estrogen receptor alpha polymorphic variants. Eur. J. Endocrinol. 156: 489-496.

Almeida S and Hutz MH (2006). Estrogen receptor 1 gene polymorphisms and coronary artery disease in the Brazilian population. Braz. J. Med. Biol. Res. 39: 447-454.

Boroumand M, Ghaedi M, Mohammadtaghvaei N, Pourgholi L, et al. (2009). Association of estrogen receptor alpha gene polymorphism with the presence of coronary artery disease documented by coronary angiography. Clin. Biochem. 42: 835-839.

Bos MJ, Schuit SC, Koudstaal PJ, Hofman A, et al. (2008). Variation in the estrogen receptor alpha gene and risk of stroke: the Rotterdam Study. Stroke 39: 1324-1326.

Chen H, Manning AK and Dupuis J (2012). A method of moments estimator for random effect multivariate meta-analysis. Biometrics 68: 1278-1284.

Cheng D, Liang B, Hao Y and Zhou W (2014). Estrogen receptor alpha gene polymorphisms and risk of Alzheimer's disease: evidence from a meta-analysis. Clin. Interv. Aging 9: 1031-1038.

Ding J, Xu H, Yin X, Zhang FR, et al. (2014). Estrogen receptor alpha gene Pvull polymorphism and coronary artery disease: a meta-analysis of 21 studies. J. Zhejiang Univ. Sci. B 15: 243-255.

Drayna D, Jarnagin AS, McLean J, Henzel W, et al. (1987). Cloning and sequencing of human cholesteryl ester transfer protein cDNA. Nature 327: 632-634. 
Egger M, Davey Smith G, Schneider M and Minder C (1997). Bias in meta-analysis detected by a simple, graphical test. BMJ 315: 629-634.

Ferrenberg AM and Swendsen RH (1988). New Monte Carlo technique for studying phase transitions. Phys. Rev. Lett. 61: 2635-2638.

Finks SW, Airee A, Chow SL, Macaulay TE, et al. (2012). Key articles of dietary interventions that influence cardiovascular mortality. Pharmacotherapy 32: e54-e87.

Gao HH, Gao LB and Wen JM (2014). Genetic polymorphisms in the ESR1 gene and cerebral infarction risk: a meta-analysis. DNA Cell Biol. 33: 605-615.

Gu Z, Wang G and Chen W (2014). Estrogen receptor alpha gene polymorphisms and risk of prostate cancer: a meta-analysis involving 18 studies. Tumour Biol. 35: 5921-5930.

Huizenga HM, Visser I and Dolan CV (2011). Testing overall and moderator effects in random effects meta-regression. Br. J. Math Stat. Psychol. 64: 1-19.

Jackson D, White IR and Riley RD (2012). Quantifying the impact of between-study heterogeneity in multivariate metaanalyses. Stat. Med. 31: 3805-3820.

Karadağ B, Güven M, Hacioğlu Y, Oz E, et al. (2009). Relationship between two estrogen receptor-alpha gene polymorphisms and angiographic coronary artery disease. Anadolu Kardiyol. Derg. 9: 267-272.

Kjaergaard AD, Ellervik C, Tybjærg-Hansen A, Axelsson CK, et al. (2007). Estrogen receptor alpha polymorphism and risk of cardiovascular disease, cancer, and hip fracture: cross-sectional, cohort, and case-control studies and a meta-analysis. Circulation 115: 861-871.

Koch W, Hoppmann P, Pfeufer A, Mueller JC, et al. (2005). No replication of association between estrogen receptor a gene polymorphisms and susceptibility to myocardial infarction in a large sample of patients of European descent. Circulation 112: $2138-2142$.

Kunnas T, Silander K, Karvanen J, Valkeapaa M, et al. (2010). ESR1 genetic variants, haplotypes and the risk of coronary heart disease and ischemic stroke in the Finnish population: a prospective follow-up study. Atherosclerosis 211: 200-202.

Li BH, Zhang LL, Yin YW, Pi Y, et al. (2012). Association between estrogen receptor alpha c.454-397T>C and c.454-351A>G and ischemic stroke risk: a systematic review and meta-analysis. Mol. Biol. Rep. 39: 9331-9338.

Lluís-Ganella C, Lucas G, Subirana I, Escurriol V, et al. (2009). Qualitative assessment of previous evidence and an updated meta-analysis confirms lack of association between the ESR1 rs2234693 (Pvull) variant and coronary heart disease in men and women. Atherosclerosis 207: 480-486.

Lu H, Chen D, Hu LP, Zhou LL, et al. (2014). Estrogen receptor alpha gene polymorphisms and breast cancer risk: a casecontrol study with meta-analysis combined. Asian Pac. J. Cancer Prev. 14: 6743-6749.

Mansur Ade P, Nogueira CC, Strunz CM, Aldrighi JM, et al. (2005). Genetic polymorphisms of estrogen receptors in patients with premature coronary artery disease. Arch. Med. Res. 36: 511-517.

Markoula S, Milionis H, Lazaros L, Spengos K, et al. (2012). Associations of ESR2 Alul (G/A) polymorphism with ischemic stroke in Caucasians. J. Neurol. Sci. 316: 126-130.

Micha R, Michas G and Mozaffarian D (2012). Unprocessed red and processed meats and risk of coronary artery disease and type 2 diabetes - an updated review of the evidence. Curr. Atheroscler. Rep. 14: 515-524.

Morgan TM, Krumholz HM, Lifton RP and Spertus JA (2007). Nonvalidation of reported genetic risk factors for acute coronary syndrome in a large-scale replication study. JAMA 297: 1551-1561.

Ovbiagele B, Goldstein LB, Higashida RT, Howard VJ, et al. (2013). Forecasting the future of stroke in the United States: a policy statement from the American Heart Association and American Stroke Association. Stroke 44: 2361-2375.

Peters JL, Sutton AJ, Jones DR, Abrams KR, et al. (2006). Comparison of two methods to detect publication bias in metaanalysis. JAMA 295: 676-680.

Roforth MM, Atkinson EJ, Levin ER, Khosla S, et al. (2014). Dissection of estrogen receptor alpha signaling pathways in osteoblasts using RNA-sequencing. PLoS One 9: e95987.

Roszkowska-Gancarz M, Kurylowicz A, Polosak J, Ambroziak M, et al. (2010). The -351A/G polymorphism of ESR1 is associated with risk of myocardial infarction but not with extreme longevity. Clin. Chim. Acta 411: 1883-1887.

Taylor F, Huffman MD, Macedo AF, Moore TH, et al. (2013). Statins for the primary prevention of cardiovascular disease. Cochrane Database Syst. Rev. 1: CD004816.

Taylor F, Ward K, Moore TH, Burke M, et al. (2011).Statins for the primary prevention of cardiovascular disease. Cochrane Database Syst. Rev. CD004816.

Wang Z, Klipfell E, Bennett BJ, Koeth R, et al. (2011). Gut flora metabolism of phosphatidylcholine promotes cardiovascular disease. Nature 472: 57-63.

Wikstrom EA, Naik S, Lodha N and Cauraugh JH (2009). Balance capabilities after lateral ankle trauma and intervention: a meta-analysis. Med. Sci. Sports Exerc. 41: 1287-1295. 
Xing Y, Jia JP, Ji XJ and Tian T (2013). Estrogen associated gene polymorphisms and their interactions in the progress of Alzheimer's disease. Prog. Neurobiol. 111: 53-74.

Xu H, Hou X, Wang N, Hui B, et al. (2008). Gender-specific effect of estrogen receptor-1 gene polymorphisms in coronary artery disease and its angiographic severity in Chinese population. Clin. Chim. Acta 395: 130-133.

Zintzaras E and loannidis JP (2005). Heterogeneity testing in meta-analysis of genome searches. Genet. Epidemiol. 28: 123-137. Zomer E, Owen A, Magliano DJ, Liew D, et al. (2012). The effectiveness and cost effectiveness of dark chocolate consumption as prevention therapy in people at high risk of cardiovascular disease: best case scenario analysis using a Markov model. BMJ 344: e3657. 